\title{
Inhibition of queen cell construction in the Cape honeybee, Apis mellifera capensis
}

\author{
LA Whiffler, HR Hepburn * \\ Rhodes University, Department of Zoology and Entomology, PO Box 94, Grahamstown, \\ 6140 , South Africa
}

(Received 29 January 1991; accepted 8 April 1991)

\begin{abstract}
Summary - Queen cell construction by Cape honeybees, Apis mellifera capensis, was analyzed with respect to queen status (mated, virgin, dead queens and queenless), source of pheromones (mandibular and abdominal tergal glands) under different test conditions (free-running queens, queens in division boards and queens in cages). The greatest inhibition of queen cell construction occurred in colonies having intact, mated and free-running queens while least inhibition occurred in queenless colonies or colonies with dead queens. The results indicate that emergency queen cell construction is inhibited by pheromones of the mandibular gland present on several different body parts.
\end{abstract}

Apis mellifera capensis / queen cell / mandibular gland / tergal gland / pheromone

\section{INTRODUCTION}

Emergency queen cell construction in honeybee colonies is inhibited by the mated queen (Huber, 1814; Müssbichler, 1952; Butler, 1954), an effect thought due to pheromones of her mandibular glands (cf Free, 1987). Indeed, just the contents of these glands smeared on an extracted, dead queen inhibit construction (Butler and Simpson, 1958). Individual compounds from this secretion cause some inhibition but less than that achieved with the whole queen (Butler and Callow, 1968). Similarly, virgin queens inhibit queen cell construction but less well than a mated queen (Butler, 1960); the former produce less mandibular gland pheromone than the latter (Butler and Paton, 1962; Pain et al, 1967). These results suggested that the full bouquet of a mated queen is required for complete and continuous inhibition of emergency queen cell construction in honeybees (cf Free, 1987).

There is a body of experimental data not consistent with the above. For example, colonies given normal mated queens and others whose mandibular glands were removed both inhibited queen cell construction to the same extent (Gary and

* Correspondence and reprints 
Morse, 1962). Likewise, in divided colonies where some bees had access only to the head and others to the abdomen of the queen, queen cell construction was inhibited in both cases (Butler, 1954). Recently, Free et al (1985) have claimed that virgin queens inhibit queen cell construction as effectively as mated queens. Collectively, these results are difficult to reconcile. We have attempted to resolve some of these difficulties by reexamining the relationship of the queen to the inhibition of emergency queen cell construction in Apis mellifera capensis and also to determine the extent to which this inhibition in capensis corresponds to that in other mellifera races.

\section{MATERIALS AND METHODS}

Experiments were performed at Grahamstown on colonies of the Cape honeybee, Apis mellifera capensis; each had $\approx 6500$ workers and a mated, laying queen in a nucleus hive with 3 frames of brood, honey and pollen and 2 empty frames. After initial dequeening and subsequent treatment, each experiment ran for $1 \mathrm{wk}$ at which time queen cells were counted.
The following queen states were investigated: 1), mated, laying queens; 2), virgin queens (hives containing these queens were fitted with excluders to prevent mating flights; 3 ), queenlessness; and 4), dead queens. These were further investigated with respect to: 1 ), mandibular glands; and 2), abdominal tergite glands, the former were surgically removed (Gary, 1961) and the latter were occluded using varnish (Velthuis, 1970). Manipulations were performed on queens lightly anaesthetized on ice.

The effects of 1), free-running queens; 2), queens in division boards; 3 ), in single-layered and 4), double-layered gauze cages were assessed. In single-layered gauze cages the workers could touch the queen and her few attendants with their antennae but not in the doublelayered cages. For the divided colonies, a board divided a Langstroth hive in 2 parts, each containing one colony. The queen was positioned in a piece of surgical rubber glove and then inserted throught the hole in the division board so that the head and thorax extended into one half of the hive and the abdomen into the other.

The queen states, pheromone glands and treatment methods were assessed in various permutations (tables I-III). A one-way analysis of variance (square-root transformation) was used to analyze the data and significance was defined as $P<0.05$.

Table I. Queen cells constructed by colonies of Cape honeybees varying in queen status.

Queen status Colonies $(n) \quad$ Queen cells constructed

$\begin{array}{lrl}\text { 1. Mated } & & \\ \text { Free-running } & 37 & 0.3 \pm 1.0 \\ \text { Died } & & \\ \text { Dead } & 29 & 5.6 \pm 6.5 \\ \text { Single gauze cage } & 39 & 4.8 \pm 3.4 \\ \text { Double gauze cage } & 5 & 3.4 \pm 4.8 \\ \text { 2. Virgin } & 3 & 0.3 \pm 0.6 \\ \text { 3. Queenless } & 17 & 0.4 \pm 1.2 \\ & 11 & 7.2 \pm 5.0\end{array}$

* Died = queen died during experiment, day unknown; dead = dead queens used as initial treatment. 


\section{RESULTS}

Comparisons of colonies tested for variations in queen quality and access to queens showed that significantly more $(P<$ 0.05 ) queen cells were constructed by queenless colonies and those with dead queens than by colonies headed by living mated or virgin queens (table l). Differences between queenless colonies and those with dead queens were not significant. Colonies with queens in single-layered gauze cages constructed significantly more queen cells than their free-running mated or virgin counterparts. Curiously, colonies with queens in double-layered gauze cages did not significantly differ from the freerunning control group (table I). The greatest level of queen cell inhibition is achieved in normally queenright colonies, least inhibition is associated with queelessness (table I).

The possible importance of mandibular and abdominal tergite gland pheromones to queen cell inhibition was assayed and the results are shown in table II. There was
- significant difference between colonies headed by intact mated or virgin queens. For the mated queen group, colonies whose queens lacked functional mandibular or abdominal tergite glands constructed significantly more $(P<0.05)$ queen cells than did the intact control group (table II). However, there were no significant differences among the colonies headed by virgin queens, normal or impaired. These colonies performed like normal colonies headed by intact, free-running mated queens (table II). Otherwise, the greatest level of queen cell inhibition is achieved in the normal queenright colony and the effect diminishes with increasing impairment of glandular function in the queens (table II).

The relative importance of the mandibular and abdominal tergite glands of queens was further assessed in division board experiments where any particular colony had access only to the head and thorax or the abdomen of the queen (table III). All of the colonies constructed significantly more queen cells than those with intact mated and free-running queens (tables I, III). Sig-

Table II. Queen cells constructed by colonies of Cape honeybees headed by queens with functional or non-functional mandibular and abdominal tergite glands.

Queens *

Mated

$+\mathrm{m} /+\mathrm{a}$

$+\mathrm{m} / \mathrm{-a}$

$-m /+a$

$-m /-a$

Virgin

$+m /+a$

$+m /-a$

$-m /+a$

$-m /-a$

$$
\begin{aligned}
& 0.3 \pm 1 \\
& 2.4 \pm 6.3 \\
& 3.5 \pm 4.1 \\
& 4.0 \pm 5.5
\end{aligned}
$$

$$
\begin{gathered}
0.4 \pm 1.2 \\
0.4 \pm 1.1 \\
0.4 \pm 1.2 \\
0
\end{gathered}
$$

\footnotetext{
* Symbols as follows: + = glands functional; - = non-functional; $m=$ mandibular; $a=$ abdominal tergite glands.
} 
Table III. Queen cells constructed by colonies of Cape honeybees whose queens were situated in division boards.

\begin{tabular}{ccc}
\hline Queens $^{*}$ & Colonies $(n)$ & Queen cells constructed \\
\hline Mated & & \\
$+\mathrm{m} / \mathrm{a}$ & 3 & $1.3 \pm 0.6$ \\
$+\mathrm{m}$ & 12 & $4.4 \pm 6.2$ \\
$-\mathrm{m}$ & 6 & $1.0 \pm 1.4$ \\
$+\mathrm{a}$ & 12 & $4.0 \pm 3.0$ \\
-a & 6 & $2.8 \pm 5.9$ \\
$+\mathrm{m}$ (dead) & 10 & $4.1 \pm 1.8$ \\
$+\mathrm{a}$ (dead) & 9 & $1.7 \pm 0.8$ \\
Virgin & & \\
$+\mathrm{m}$ & 4 & $4.8 \pm 5.3$ \\
$+\mathrm{a}$ & 4 & $1.0 \pm 1.4$ \\
\hline
\end{tabular}

\footnotetext{
* Colonies only had access to either the head and thorax $(m)$ or abdomen (a) of the queen. + = gland functional; - = non-functional. In the control colonies $(+\mathrm{m} /=\mathrm{a})$ the division board was imcomplete so that the colony had access to the whole but restrained queen.
}

ificantly more $(P<0.05)$ queen cells were constructed among colonies of the division board control group (table III) than amongst their free-running counterparts (table I), a result suggesting that important treatment effects are associated with division board assays. But again, impairment of glandular function in the queens results in increased queen cell construction (table III).

\section{DISCUSSION}

Although control of queen cell construction has been ascribed to pheromones (cf Free, 1987), the number of cells constructed on queen loss might also be related to the availability of eggs and young larvae (Butler, 1954) or to colony size (Fell and Morse, 1984). In our experiments all of the colonies were equalised for brood and col- ony size. Nonetheless, we noted a considerable variation in the numbers of queen cells constructed both within and among the treatment groups. This result is similar to others (Fell and Morse, 1984; Winston et al, 1989; Kaminski et al, 1990) and there is no obvious explanation for the observed variations.

In our experiments most queen cells were constructed by queenless colonies and those with dead queens (tables $I$ and II). Even though workers had direct contact with the dead queens, queen cell construction was not inhibited (tables $I$ and II). Caged queens did not inhibit the construction of queen cells (table I), a result similar to those of Müssbichler (1952) and Butler (1954). (Results obtained from colonies whose queens were in double-layered cages are regarded as anomalous.) That the worker bees need to have direct contact with a living queen for queen cell construction to be inhibited is confirmed. 
Colonies given a mated queen without mandibular glands (and/or tergite glands) constructed significantly more queen cells than the colonies given a mated queen with intact mandibular glands and/or tergite glands (tables I and II). This differs from the results of Butler (1961) and Gary and Morse (1962) that queen cell construction was as effectively inhibited by mated queens with or without mandibular glands. The differences between these results are not easily explained unless the pheromone(s) secreted from the mandibular glands (particularly 9ODA and 9HDA) are not solely responsible for inhibiting queen cell construction (Butler and Callow, 1968; Free, 1987), or are not confined to the head.

Virgin queens with or without mandibular glands (and/or abdominal tergite glands) also inhibited queen cell construction (tables I, II), results consistent with those of Free et al (1985). This might have been expected of the Cape honeybee because the bouquets of the mandibular glands of virgin and mated queens are so similar in this race (Crewe, 1988). This is not the case for other races (Crewe, 1988) and it is reasonable to conclude that secretions of a queen's mandibular glands that might spread onto the head of a queen cannot alone account for the inhibition of queen cell construction in the Cape or any other honeybee race. The abdominal tergite glands now appear to be an unlikely source of such pheromones because both mated or virgin queens with occluded tergite glands inhibited queen cell construction (tables I and II).

Similar numbers of queen cells were constructed in the division board experiments when the workers had access to either head alone (with/without mandibular glands) or abdomen alone (with/without tergite glands) of a mated, virgin or dead queen (table III), results similar to those of
Butler (1954). Although these colonies constructed slightly more queen cells than colonies given a mated or virgin queen with intact mandibular and tergite glands, these differences were not significant.

It is evident that inhibition of queen cell construction does not operate on an all-ornone basis but is a graded series of response (tables I-III). The results of our experiments and those of other workers (cf Introduction) can be accommodated within the hypothesis that the inhibiting scent of the queen may be found on all parts of her body and lodged in the waxes of the epicuticular layer (Butler, 1954, 1961). This view is strongly supported by the recent discovery that all major body parts of queens, especially the head and legs, carry sufficient mandibular exudate to be highly attractive to worker honeybees (Engels et al, 1990; Slessor et al, 1990). The results of tables I-III can be interpreted such that inhibition of queen cell construction is primarily mediated by pheromones of the queen's mandible but as expressed in the context of the whole body surface of the queen as originally supposed by Butler (1954, 1961).

Whatever the full explanation for the inhibition of queen cell construction in queenright colonies may prove to be, it is noteworthy that, despite other extraordinary aspects of its general biology (Ruttner, 1988), the Cape honeybee differs from other races of mellifera only in degree, not kind. This is consistent with recent data that fundamental principles of suppression of ovarial development as it operates among races of mellifera is equally applicable to the Cape honeybee (Hepburn et al, 1991).

Résumé - Inhibition de la construction des cellules royales chez l'abeille du Cap, Apis mellifera capensis Escholtz. 
On a étudié sur des colonies d'abeilles du Cap (Apis mellifera capensis) l'influence de l'état de la reine (1: reine féconde et pondeuse, 2 : reine vierge, 3 : reine absente (colonie orpheline) et 4 : reine morte) sur l'inhibition de la construction des cellules royales. Chacun de ces états a été étudié en fonction de 2 variables propres à la reine (les glandes mandibulaires et les glandes tergales). On a aussi testé l'influence de reines libres, de reines placées derrière une grille à reines et de reines encagées.

Les ouvrières des colonies orphelines et des colonies possédant un reine morte ont construit significativement plus de cellules royales que les colonies qui avaient une reine vivante féconde ou une reine vierge (tableau I). Peu importe que la reine ait été derrière une grille, ou que ses glandes mandibulaires et/ou tergales aient été supprimées (tableau II et III). Un nombre semblable de cellules royales a été construit lorsque les ouvrières avaient accès soit à la tête soit à l'abdomen d'une reine féconde, vierge ou morte (avec ou sans glandes mandibulaires et/ou tergales). Les colonies possédant une reine dépourvue de glandes mandibulaires ou tergales ont construit plus de cellules royales que celles qui avaient une reine avec ces mêmes glandes intactes.

Un nombre significativement plus grand de cellules royales a été construit dans les colonies qui possédaient une reine féconde sans glandes madibulaires que dans celles qui avaient une reine féconde avec glandes mandibulaires. Le nombre de cellules royales construit dans des colonies avec une reine vierge est le même, que leurs glandes mandibulaires et/ou tergales aient été on non supprimées. Les colonies qui avaient une reine encagée (derrière une simple grille) ont construit plus de cellules royales que celles qui avaient une reine libre de se mouvoir sur les rayons.
Ce sont les reines fécondes et les reines vierges avec glandes mandibulaires et tergales intactes qui, de toutes les combinaisons testées, ont exercé la plus forte inhibition de la construction des cellules royales. On en conclut que l'inhibition de la construction des cellules royales est produite en premier lieu par les phéromones des glandes mandibulaires mais qu'elle se manifeste sur toute la surface du corps de la reine.

Apis mellifera capensis / cellule royale / glande mandibulaire / glande tergale / phéromone

\section{Zusammenfassung - Hemmung der Er- richtung von Weiselzellen bei der Kap- biene, Apis mellifera capensis. Es wurden mit Völkern der Kapbiene, Apis mellifera capensis, Versuche über die Hemmung der Errichtung von Weiselzellen durchgeführt. Die folgenden Königinnen- Stadien wurden untersucht: (1) Begattete, legende Königinnen; (2) unbegattete Köni- ginnen; (3) Weisellosigkeit; (4) tote Köni- ginnen. Diese Stadien wurden weiter abge- wandelt in Hinblick auf den Zustand der Königin, unf zwar hinsichtlich (1) des Zu- stands der Mandibeldrüsen und (2) der Tergittaschendrüsen. Zusätzlich wurden die Effekte (1) einer frei laufenden Königin, (2) von Königinnen in Seitenabteilen und (3) von gekäfigten Königinnen geprüft.}

Die Arbeitsbienen in weisellosen Völkern oder in Völkern mit toten Königinnen errichteten signifikant mehr Weiselzellen als Völker mit legenden oder unbegatteten Königinnen ( $T a b$ 1). Es spielte keine Rolle, ob sich die Königin in einem Seitenabteil befand oder ob ihre Mandibeldrüsen oder Tergittaschendrüsen entfernt worden waren oder nicht (Tab 2, 3). Eine ähnliche Zahl an Weiselzellen wurde errichtet, wenn die Arbeiterinnen Zugang zum Kopf oder 
Hinterleib einer begatteten, einer unbegatteten oder einer toten Königin (mit oder ohne Mandibeldrüsen und/oder Tergittaschendrüsen) hatten. Völker mit Königinnen ohne Mandibeldrüsen oder Tergittaschendrüsen errichteten mehr Weiselzellen als Völker mit intakten Drüsen.

In Völkern mit begatteten Königinnen ohne Mandibeldrüsen wurden signifikant mehr Weiselzellen errichtet als in Völkern mit begatteten Königinnen mit Mandibeldrüsen. Die Zahl der Weiselzellen in Völkern mit unbegatteten Königinnen war dieselbe, gleichgültig, ob ihre Mandibeldrüsen und/oder Tergittaschendrüsen entfernt waren oder nicht. Völker mit gekäfigten Königinnen (mit einfachem Gitter) errichteten mehr Weiselzellen als Völker mit frei auf den Waben laufenden Königinnen. Begattete oder unbegattete Königinnen mit intakten Mandibel- und Tergittaschendrüsen zeigten bei allen Versuchen hinsichtlich der Errichtung von Weiselzellen die stärkste Wirkung. Es wird daraus der Schlu $\beta$ gezogen, daß die Hemmung der Errichtung von Weiselzellen in erster Linie von den Pheromonen der Mandibeldrüsen bewirkt wird, aber auf dem Wege über die gesamte Körperoberfläche der Königin.

\section{Apis mellifera capensis / Weiselzelle / Mandibeldrüse / Tergittaschendrüse / Pheromon}

\section{REFERENCES}

Butler CG (1954) The method and importance of the recognition by a colony of honey-bees $(A$ mellifera $L$ ) of the presence of its queen. Trans $R$ Entomol Soc Lond 105, 11-29

Butler CG (1960) Queen substance production by virgin queen honeybees (Apis mellifera). Proc R Entomol Soc Lond A 35, 170-171

Butler CG (1961) The scent of queen honeybees ( $A$ mellifera) that causes partial inhibi- tion of queen rearing. $J$ Insect Physiol 7, 258264

Butler CG, Simpson J (1958) The source of queen substance of the honeybee (Apis mellifera $\mathrm{L}$ ). Proc $R$ Entomol Soc Lond A 33 , 120-122

Butler CG, Paton PN (1962) Inhibition of queen rearing by queen honeybees (Apis mellifera $L$ ) of different ages. Proc $R$ Entomol Soc Lond A 37, 114-116

Butler CG, Callow RK (1968) Pheromones of the honeybee (Apis mellifera L): the "inhibitory scent" of the queen. Proc R Ento$\mathrm{mol}$ Soc Lond A 43, 62-65

Crewe RP (1988) Natural history of honey-bee mandibular gland secretions: development of analytical techniques and the emergence of complexity. In: Africanized Honey Bees and Bee Mites (Needham GR, Page RE, Delfinado-Baker $M$, Bowman CE, eds) Ellis Horwood Limited, Chichester, UK

Engels W, Francke W, Lubke G (1990) Neue Dufstofanalysen bei Bienenkoniginnen (Apis mellifera carnica). Apidologie 21, 355-357

Fell RD, Morse RA (1984) Emergency queen cell constructionin the honey bee colony. Insectes Soc 32, 221-237

Free JB (1987) Pheromones of Social Bees. Chapman and Hall, London

Free JB, Ferguson AW, Simkins JR (1985) Influence of virgin honeybees (Apis mellifera) on queen rearing and foraging. Physiol Entomol $10,271-274$

Gary NE (1961) Mandibular glands extirpation in living queen and worker honeybees (Apis mellifera L). Ann Entomol Soc Am 54, 529531

Gary NE, Morse RA (1962) Queen cell construction in the honey bee (Apis mellifera L) colonies headed by queens without mandibular glands. Proc R Entomol Soc Lond A 37, 7678

Hepburn HR, Magnuson P, Herbert L, Whiffler LA (1991) Ovarial development in workers of the Cape honeybee. J Apic Res (submitted)

Huber F (1814) Nouvelles Observations sur Les Abeilles, 2. Dadant, Hamilton III (trans! 1926)

Kaminski LA, Slessor KN, Winston ML, Hay NW, Borden JH (1990) Honeybee response 
to queen mandibular pheromone in laboratory assays. J Chem Ecol 16, 841-850

Müssbichler A (1952) Die Bedeutung ausserer Einflusse und der Corpora Allata bei der Afterweisel-entstehung von Apis mellifera. Z Vgl Physiol 34, 207-221

Pain J, Barbier M, Roger B (1967) Dosages individuels des acides céto-9-décène-2-oïque et hydroxy-10-décène-2-oique dans les têtes des reines et des ouvrières d'abeilles. Ann Abeille 10, 45-52

Ruttner F (1988) Biogeography and Taxonomy of Honeybees. Springer, Berlin
Slessor KN, Kaminski LA, King GGS, Winston ML (1990) Semiochemicals of the honeybee queen mandibular glands. $J$ Chem Ecol 16 , 851-860

Velthuis HHW (1970) Queen substance from the abdomen of the queen honeybee. $Z \mathrm{Vgl}$ Physiol 70, 210-222

Winston ML, Slessor KN, Willis LG, Naumann K, Higo H, Wyborn M, Kaminski LA (1989) The influence of queen mandibular pheromones on worker attraction to swarm clusters and inhibition of queen rearing in the honey bee (Apis mellifera L). Insectes Soc 36, 15-27 